\title{
The 2030 Agenda and U.S. Global Development Policy
}

\author{
Alida Tomja \\ Department of Political Science, Faculty of Political Science and Law, “Aleksander Moisiu” University, Albania
}

How to cite this paper: Tomja, A. (2018). The 2030 Agenda and U.S. Global Development Policy. The Educational Review, USA, 2(8), 447-457. http://dx.doi.org/10.26855/er.2018.08.005

Corresponding author: Alida Tomja, Ph. D., Department of Political Science, Faculty of Political Science and Law, "Aleksander Moisiu" University, Albania.

\begin{abstract}
2030 Agenda for Sustainable Development is the concretization of a continuous effort between states and other stakeholders in order to transform the world. In the process of negotiations that has taken several years, United States, exercising global leadership, have played an active role. They have been willing to cooperate with the global community by drafting a plan on the future of sustainable development. The most important thing is that this prominent actor of the international order will continue to play a crucial role in ensuring the success of this Agenda. Therefore, the purpose of this paper is to introduce the concrete steps taken by U.S. government for sustainable development in the context of global challenges of this century. By understanding the position and responsibility as the most powerful country of the international system, with the capacity to produce public goods, the United States are working in close partnership with countries and communities of the world, to avoid negative climate changes, to solve environmental problems and to modernize the global cooperation. Besides these issues, the intention of this paper is to make clear the U.S projects regarding the global health, food security, gender equality, education, open government and apparent conflicts. The above-mentioned are the focus of 2030 Agenda and constitute the main lines of this paper. Based on literature, documentation review and reports of the White House, United States Agency for International Development (USAID), US Environmental Protection Agency (EPA) etc., we conclude that even the U.S, a global leader, cannot achieve alone the 2030 Agenda goals, which are really ambitious. In order to achieve successfully the sustainability development goals it's necessary to work in partnership with other stakeholders, including governments, international institutions, communities around the world, private sector, research institutes and common citizens. The challenges of this century are forcing America to use power not over the others but with others because these goals are designed to work together.
\end{abstract}

\section{Keywords}

2030 Agenda, Sustainable Development, U.S Policy, International Development

\section{What Is Sustainable Development?}

Development is synonymous with change which is an inevitable truth of the world in which we live. It constantly brings new challenges and opportunities. The history of changes is rumored about 2500 years ago when Heraclitus, the ancient greek philosopher, said that the change is the only constant in life. However, we are interested in policies that enable sustainable development in the context of inevitable changes.

But what should we understand with Sustainable Development? The highly quoted definition of sustainable development is 
contained at the Bruntland Commission's report: "Our common future". According to this report, development is sustainable if it meets the needs of the present without compromising the ability of future generations to meet their needs (UN General Assembly Report: 1987). This definition implies the goal of maintaining economic progress, while safeguarding the long-term value of the environment. So it is a mix between environmental policies and development strategies.

In fact, the sustainable development concept can be interpreted in different ways, but basically it is an approach to a new development model which takes into account the environmental, social and economic aspects, in a globalized world. The overall goal is the long-term environmental and socio-economic stability which is accessible only through integration and recognition of the concerns in these areas, throughout the decision-making process. Climate change, ecological and social crises, food security, global population growth, depletion of natural resources, extreme poverty, differences between developed and emerging economies, natural disasters etc. have already emerged as global problems that need solutions. This is exactly the goal of sustainable development. Through its programs, it aims to create sustainable models to protect environmental quality and to reduce social-economic problems at regional and global level, by building strong and healthy societies, meeting the age diverse needs of people in existing communities and by promoting personal well-being, social cohesion, involvement, creating so equal opportunities and for all.

Eradicate poverty in all forms and dimensions, is a prerequisite for sustainable development. To this end, must be created equal opportunities by reducing inequalities, raising basic living standards, promoting equal social development, but always promoting integrated and sustainable management of natural resources and ecosystems. In a study by the US National Academy of Sciences on Sustainable Development, has been evidenced that a wide range of literature and definitions is circulated to this phenomenon. In an effort to accommodate the multiple ideas, they structured the sustainable development views as in the figure 1.

\begin{tabular}{|c|c|c|}
\hline What is to be sustained? & & What is to be developed? \\
\hline $\begin{array}{l}\text { NATURE } \\
\text { earth } \\
\text { biodiversity } \\
\text { ecosystems } \\
\text { LIFE SUPPORT } \\
\text { SYSTEMS } \\
\text { services } \\
\text { sources } \\
\text { environment }\end{array}$ & $\begin{array}{l}\text { FOR HOW LONG? } \\
25 \text { years } \\
\text { "Now and in } \\
\text { the future" } \\
\text { Forever }\end{array}$ & $\begin{array}{l}\text { PEOPLE } \\
\text { survival of children } \\
\text { longevity } \\
\text { education } \\
\text { equal opportunities } \\
\text { THE ECONOMY } \\
\text { wealth } \\
\text { productive sectors } \\
\text { consumption }\end{array}$ \\
\hline $\begin{array}{l}\text { COMMUNITIES } \\
\text { cultures } \\
\text { groups } \\
\text { countries }\end{array}$ & & $\begin{array}{l}\text { SOCIETY } \\
\text { institutions } \\
\text { social capital } \\
\text { states } \\
\text { regions }\end{array}$ \\
\hline
\end{tabular}

Figure 1. Definitions of sustainable development.

Source: U.S. National Research Council, Policy Division, Board on Sustainable Development, Our Common Journey: A Transition toward Sustainability. Washington, DC: National Academy Press, 1999; quoted in Robert W. Kates, Thomas M. Parris \& Anthony A. Leiserowitz. 2005, "What is Sustainable Development? Goals, Indicators, Values, and Practice”, Environment: Science and Policy for Sustainable Development, Vol. 47, No. 3, pg. 8-21. 
As seen above, regarding the question "what must be sustainable", the board has been able to identify three main categories: nature, life support systems and community, each detailed with their respective subcategories. As seen above, regarding the question "what must be sustainable", the board has been able to identify three main categories: nature, life support systems and community, each detailed with their respective subcategories.

\section{Understanding the 2030 Agenda}

The 2030 Agenda for Sustainable Development is the concretization of a constant effort between states and other actors to improve everyone's life. Therefore, this agenda represents an action plan for people, planet and prosperity. It aims to strengthen global peace through the promise that no one seems to be left behind. Its vision consists in respecting human rights, equality and non-discrimination. Also, through it is aimed to reduce poverty in all its forms, promoting sustainable and inclusive economic growth, social development and environmental protection.

It's understandable that the fulfillment of these goals requires the involvement of many stakeholders, taking into account not only governments but also economic actors, civil society, etc. However, the primary role belongs to the states as the main actors of the international system. In this context, sustainable development is included in the "Millennium Development Goals" (United Nations Development Program) established by and for all UN member states. Meanwhile, the 17 Sustainable Development Goals adopted by world leaders on 25-27 September 2015 at a historic summit of this organization were included in what would be known as the "Transforming the World: The 2030 Agenda for Sustainable Development".

This agenda, which was adopted by the 193 UN member states, consists in a statement, 17 Sustainable Development Goals, 169 targets, a section on means of implementation, renewed global partnership and a framework for review and follow-up. It has officially entered into force on January 1, 2016, until December 2030 (UN-2030 Agenda).

The above initiative is not new for the United Nations, it is the product of a continuous work on the results of the 2002 Sustainable Development Summit, 2010 Summit on Millennium Development Goals, the results of the UN Conference on Sustainable Development held in Rio de Janeiro in 2012 (Rio + 20) and the opinions of people around the world. It is also worth pointing out that the Millennium Development Goals, which led to the most successful anti-poverty movement in history, have served as a springboard for the 2030 Agenda. On the other hand, the latter paved the way for the global climate change agreement reached at the 21st Paris Summit on December 11, 2015, known as the Paris Climate Change Agreement. The particularity of the 2030 Agenda is that, to be implemented, it requires action from all countries, whether these are poor, rich or middle-sized by the level of economic development. In this context, we can say that 2030 Agenda 2030 is of a universal nature.

After more than a year of inclusive discussions and consultations, the working group proposed 17 concrete objectives. Intergovernmental negotiations on the composition of the objectives have lasted more than two years and have involved many contributions from civil society and other stakeholders. It states that the eradication of poverty must go hand in hand with a plan for economic growth, which should address a range of social needs including education, health, social protection and employment, climate change and environmental protection. It also covers issues such as inequality, infrastructure, energy, consumption, biodiversity, oceans and industrialization. But, let's get acquainted with the concrete goals of this agenda by briefly addressing each of them.

\subsection{Sustainable Development Goals of the 2030 Agenda (UN, Sustainable Development Knowledge Plat- form)}

End Poverty in All Its Forms Everywhere

This objective, which calls for ending poverty in all its forms by 2030, aims to provide social protection for the poor and vulnerable, to increase access to basic services and to support people in need and those injured by extreme climatic phenomena or 
other economic, social and environmental disasters.

End Hunger, Achieve Food Security and Improved Nutrition and Promote Sustainable Agriculture

The second objective, which aims to end hunger and all forms of malnutrition by the end of 2030, is committed to a universal approach to safe and adequate food at any time of the year. Fulfilling such an objective requires sustainable food production systems, technologies to increase agricultural productivity, markets and international cooperation for infrastructure investment. Ensure Healthy Lives and Promote Well-Being for All at All Ages

Through this objective is intended to ensure health and well-being for all, at every stage of life. There is a real need for intensive work on major health problems as transmitted and environmental diseases, but also problems with medications and vaccines. What is needed is a safe, effective and quality approach in this area; more research, increased health financing, and strengthening the capacity of all countries to manage and reduce health risks.

Ensure Inclusive and Quality Education for All and Promote Lifelong Learning

Despite the progress made in the area of universal primary education in the framework of the "Millennium Development Goals" initiative, statistics of children who do not attend this educational level show a still unresolved gap. Sustainable Development Objectives clearly acknowledge that this problem has to be ended, although the international community seems to attach more importance to quality and equity in this area.

Achieve Gender Equality and Empower All Women and Girls

Gender equality and empowerment of women have advanced in recent decades. However, gender equality remains a constant challenge almost anywhere in the world and the lack of equality is a major obstacle to sustainable development.

Ensure Access to Water and Sanitation for All

Water and sanitation, two critical factors for the survival of humans and the planet, are at the heart of sustainable development. The sixth objective, not only addresses issues related to drinking water, sanitation and hygiene but also aims to improve the quality and sustainability of water resources throughout the world.

Ensure Access to Affordable, Reliable, Sustainable and Modern Energy for All

Energy is crucial to achieving all sustainable development objectives, ranging from eradicating poverty, advancing health, education, water supply, industrialization, and combating climate change.

Promote Inclusive and Sustainable Economic Growth, Employment and Decent Work for All

Sustainable and inclusive economic growth is indispensable for achieving sustainable development. What is recently noticed is that the annual growth rate of real GDP per capita has been declining. While in year 2000 we had a growth of 3 percent and in 2010 - 2.8 percent, year 2014 marked an increase of no more than 1.3 percent. Another characteristic is that developing regions had a much faster growth than developed regions. It's intended to stimulate continued and steady economic growth.

Build Resilient Infrastructure, Promote Sustainable Industrialization and Foster Innovation

The above goal includes three important aspects of sustainable development: infrastructure, industrialization and innovation. Industrialization promotes economic growth, creates employment opportunities and thus reduces poverty.

Reduce Inequality within and among Countries

The tenth goal aims to reduce income inequalities that vary depending on age, gender, disability, race, ethnicity, origin, religion or country.

Make Cities Inclusive, Safe, Resilient and Sustainable

This goal is of particular significance if we consider that more than half the world's population lives in urban areas. By 2030, it is predicted that 6 in 10 people will be urban residents.

Ensure Sustainable Consumption and Production Patterns

Sustainable development requires minimizing the toxic materials and waste generated during the production and consumption 
process.

Take Urgent Action to Combat Climate Change and Its Impacts

Climate change is one of the biggest threat that requires immediate initiatives. Their reduction is an integral part of achieving sustainable development objectives.

Conserve and Sustainably Use the Oceans, Seas and Marine Resources

Oceans, along with coastal and marine resources, play an essential role in human well-being as well as in socio-economic development all over the world. They also regulate the global ecosystem by absorbing heat and carbon dioxide from the atmosphere, also protecting coastal areas from flooding and erosion. Sustainable use and the protection of marine, coastal ecosystems and their biological diversity are essential for the fulfillment of 2030 Agenda.

Life on Land-Sustainably Manage Forests, Combat Desertification, Halt and Reverse Land Degradation, Halt Biodiversity Loss

This objective places emphasis on sustainable forest management, the prohibition of land degradation process and biodiversity loss.

Promote Peaceful and Inclusive Societies for Sustainable Development

This objective aims justice for all and the establishment of effective, accountable and comprehensive institutions at all levels Revitalize the Global Partnership for Sustainable Development

Achieving the ambitious goals of the 2030 Agenda requires broad-based global partnership that unites governments, civil society, the private sector, the United Nations system and all available resources. The support for developing countries, especially for less developed countries, remains essential for equal progress. All the above-mentioned objectives are intended to be universally applied over the next fourteen years.

\section{U.S. Global Development Policy and 2030 Agenda}

The 2030 Agenda, which embodies the hopes and aspirations of many people around the globe for meaningful change and progress, would be senseless not to become part of the United States' own political agenda, which have demonstrated that are ready to cooperate with the global community by developing a plan for the future of sustainable development. Through this plan, the US, along with other countries of the world have promised to be seriously engaged in terms of sustainable global development by prioritizing policies with long-term transformational impact.

It is worth pointing out that in the U.S, the adoption of the 2030 Agenda coincides with an increase of bipartisan consensus regarding the priority that should be given to sustainable global development. This consensus was also found on the American people, who have contributed significantly to international emergencies and global development. While not underestimating the achievements under the Millennium Development Goals, in which is worth noting: halving the number of people living in extreme poverty, with less than 1.25 dollars a day, since 1990; halving the percentage of malnourished people in developing regions; halving the rate of infant mortality; promotion of gender equality (The Millennium Development Goals-UN Report 2015), etc., the United States has described the new agreement as very important.

As a global leader for more than half a century, the United States has taken some initiatives in terms of sustainable international development where can be mention the creation of the Millennium Challenge Corporation (MCC) ${ }^{1}$ and the President's Emergency Plan for AIDS Reduction (PEPFAR-Myra Sessions) ${ }^{2}$ under the direction of President George W. Bush. Meanwhile, the

\footnotetext{
1 The Millennium Challenge Corporation (MCC) is a new and independent agency created by the US Congress in January 2004, which is helping to guide the fight against global poverty. For more information on this agency see: https://www.mcc.gov/about

2 The President's emergency plan for AIDS Relief also known as the PEPFAR, or the Emergency Plan, is a five-year US government plan to prevent HIV / AIDS through care and treatment programs in developing countries. This project, which was initiated in 2003, represents the largest global health initiative dedicated to a single illness.
} 
Obama administration declared its first development policy in 2010. For the first time, sustainable global development was consolidated as a pillar of American power and recognized as a strategic, economic and moral imperative for the United States. The President presented a vision that centered on the principles and objectives of the 2030 Agenda, including: broad-based economic growth; democratic governance; international partnership for financing sustainable development; building sustainable systems to meet basic human needs, etc.

Today, US investments are better oriented to have impact and achieve results in terms of sustainable global development; to establish important links with other donors, non-governmental partners and the private sector; using more efficiently the power of technology and innovation to reach most of the 2030 Agenda goals. America's leadership has been very important to achieve goals in the following areas:

\subsection{The American Agenda of Ensuring Healthy Lives and Well-Being for All}

During the Obama administration, US contributions to the Global Fund to Fight AIDS, Tuberculosis and Malaria amounted to 7.2 billion dollars, while they have provided more than 13.2 billion (The White House, Office of the Press Secretary For Immediate Release, September 2015) ${ }^{3}$ from other sources. Through these investments, the United States continues to lead the world in the global health field, working to end epidemics like HIV/AIDS (thus contributing to a generation without AIDS), to fight malaria and tuberculosis, to reduce causes of infant deaths, mothers, and to strengthen health systems.

Through 2016, the United States has made public a number of new and ambitious targets, including the goal of treating a total of 11.4 million people with HIV/AIDS by the end of 2016 and 12.9 million people by the end of the year 2017 ; to achieve 25 percent reduction in HIV cases among adolescent girls and young women (ages 15-24) in 10 sub-Saharan African countries in close collaboration with partners by the end of 2016; and to reduce 40 percent of HIV cases to this target group by the end of 2017 (Inter Action a United Voice for Global Change).

Also, the Ebola epidemic in West Africa continues to raise the attention and global resources of the international community to eliminate active cases and help affected countries. Realistically, the United States, along with partners from around the world, have made significant progress in the fight against this phenomenon, which reached an alarming level in September 2014. For decades, the US has invested in the health of African people, has helped and trained in partnership with African countries its health and science professionals to meet common challenges. They also enabled the establishment of National Public Health Institutes in several countries of this continent, including Ethiopia and Kenya. Among other things, these centers will also serve to the researchs in the field of public health. The US goal is that in the following years, to accelerate the progress towards a safer world by infectious disease threats through the construction of collective prevention and control capacity towards them.

One of the ongoing concerns of the US, regarding the area we are talking about (which coincides with the third objective of the 2030 Agenda for Sustainable Development) has been the fight against biological threats and the prevention of epidemic outbreaks future. That is why the United States has been committed to helping at least 30 countries which in the context of meeting the Global Health Security Agenda (The White House, Office of the Press Secretary for Immediate

For more information see: Myra Sessions, “Overview of the President's Emergency Plan for AIDS Relief (PEPFAR)”, Center for Global Development. URL: http://www.cgdev.org/page/overview-president\%E2\%80\%99s-emergency-plan-aids-relief-pepfar

3 Established in 2002, the Global Fund is a 21 st century organization to end epidemics such as AIDS, Tuberculosis and Malaria. It works based on partnership between governments, civil society, private sector, and people affected by the diseases. The above data are available at: The White House, Office of the Press Secretary For Immediate Release, "Fact Sheet: U.S. Global Development Policy and Agenda 2030: President Obama's Commitment to Global Development" September 27, 2015, available at: https://www.whitehouse.gov/the-press-office/2015/09/27/fact-sheet-us-global-development-policy-and-agenda-2030; See also: The Henry J. Kaiser Family Foundation, Global Health Policy, "The U.S. \& The Global Fund to Fight AIDS, Tuberculosis and Malaria" September 14, 2016, available at: http://kff.org/global-health-policy/fact-sheet/the-us-the-global-fund-to- fight- aids -tuberculosis-and-malaria/ 
Release, July 2015) ${ }^{4}$ objectives, should increase their national capacity to prevent and respond to the threats of infectious diseases, whether they are natural, accidental, or intentional. The United States in close co-operation with the G7 leaders intends that within the next five years they may offer collective help in this regard for at least 60 countries (Office of the Press Secretary for Immediate Release). Also, in order to fulfill the aforementioned objective, the United States has announced targets for ending not only the Ebola epidemic, but also the fight against antibiotic-resistant bacteria, the improvement of global biosecurity, and the prevention of bioterrorism. The advance of these objectives necessarily requires cooperation and partnership with the global community. Therefore, the White House has organized several top-level meetings with countries around the world on these issues.

\subsection{Achieving Gender Equality}

While gender equality is ranked as the fifth objective of the 2030 Sustainable Development Agenda, the United States admit that none of the other objectives of this agenda can be achieved without focusing on girls and women. In fact, even though twenty years have passed since the Beijing Declaration and the assertion that "women's rights are human rights", women and girls around the world continue to face inequalities in public and private spheres. According to USAID, around 600 million girls are growing in the developing world (USAID: 2015). These figures are indicative of the fact that women are a powerful force for change. But progress cannot be achieved if gender inequality thrives. In order to develop societies, women and girls should have access to education, health and technology. Above all, they should have equal rights and opportunities, because only like this, human potential can be used on a transformational scale.

Regarding the fulfillment of this objective, the United States has shown considerable commitment. Promoting gender equality and empowering women has been and continues to be a priority for the US government, which has worked to combat discrimination; to eliminate violence against women and girls both inside and outside the country; to extend health care to women, including sexual and reproductive health; to support their business activities, and to encourage women's political and economic leadership. In fact, America has historically worked to bring women of different backgrounds into policy shaping at every level of government and to have their voices heard anywhere in the world.

Globally, America is investing in education of this gender and the security that needs to be provided in terms of infectious diseases such as HIV / AIDS. In their view, educated and empowered women and girls are critical factors for achieving sustainable peace, security and prosperity for America and the whole world. Meanwhile, according to the World Bank, countries with greater gender equality are more prosperous and competitive. Hence, the United States government is committed internally and globally to advance women's empowerment, gender equality and human rights.

The main lines on which the United States has worked to fulfill this objective, by designing programs that improve their lives and allocating considerable funds, are:

1) Improving women's health;

2) Fighting violence against women and girls;

3) Promoting women's political and economic leadership;

4) Combating trafficking in human beings;

5) Promoting girls' education.

One of the initiatives that is worth mentioning regarding gender equality is "Equal Opportunity for the Future" a new multilat-

\footnotetext{
4 The Global Health Security Agenda (GHSA) aims to promote the implementation of the International Health Regulations, the World Health Organization and other global health security frameworks. We find included non-governmental sector, academic and research institutes, expert groups, industry and the private sector. In addition to the United States, the GHSA steering group includes Kenya, Canada, Chile, Finland, India, Indonesia, Italy, the Kingdom of Saudi Arabia and the Republic of Korea. The White House, Office of the Press Secretary for Immediate Release, "Fact Sheet: The Global Health Security Agenda", July 28, 2015, available at: https://www.whitehouse.gov/the-press-office/2015/ 07/28 / fact-sheet-global-health-security-agenda
} 
eral initiative, led by the United States and designed to encourage member countries to empower women's economic and political affairs. Established since 2012, this organization continues to be active, and the partnership has grown from 12 to 27 countries, including the European Union. All member states, led by the United States, have undertaken some legal and political reforms to ensure that women are actively involved in public life at local, regional and national level. One of the US objectives for 2017, is the further expansion of the members of this initiative, even their duplication, in order to advance the fulfillment of 2030 Agenda. Because, in a global context, the United States can not fulfill all alone the ambitious goals of the aforementioned Agenda.

\subsection{Achieving Food Security}

Following the Aquila Summit held in 2009 among the G-8 nations, the Obama administration urged world leaders to work harder in addressing food insecurity. In this view, that coincides with the second objective of the 2030 Agenda, the United States has led a campaign in support of agriculture (Marian L. Lawson, Randy Schnepf \& Nicolas Cook: 2016), while food and nutrition security continous to be at the top of the US agenda.

Judging that investments in the development of agriculture and nutrition improvement will have a transformative impact on reducing hunger and extreme poverty, the White House has taken the initiative to improve feed quality in the future, Feed the Future (Marian L. Lawson, Randy Schnepf \& Nicolas Cook: 2016) ${ }^{5}$. Within the latter, the US administration has worked closely with partners to support economic growth through the development of the agricultural sector. US policies have enabled higher productivity, higher incomes, improved nutrition, and more dynamic economies.

Also, the United States has started, together with other donors, the Global Agriculture and Food Security Program (GAFSP), an innovative program that has helped to increase agricultural productivity in 25 low-income countries (White House, Fact Sheet). In this line, the United States has invested in the promotion of global collective actions. Together with the G-7 member states and African leaders, they are further contributing to the sustainable development of the private sector for African agriculture, for the next 14 years.

\subsection{Fight against Extreme Poverty}

Development policies and most of the initiatives led by the United States are aimed at combating extreme poverty and promoting sustainable economic growth, equal opportunities, open and transparent governance. To further this mission, USAID is committed to identify the causes, trends, challenges associated with this phenomenon and the development of a strategy through which this problem can be addressed.

The United States, through USAID, has focused more on those countries where extreme poverty is very pronounced. They are working with governments in developing countries, civil society, other donors, local actors and the private sector to determine the most effective methods. This commitment involves much more than providing a direct assistance to extremely poor countries. In the framework of cooperation with partners to implement the 2030 Agenda for Sustainable Development, the US vision for ending extreme poverty consisted in designing a concrete strategy which although not providing solutions to all problems, has contributed in clarifying the best strategies to address this problem.

The greatest success in meeting this objective, the United States has achieved through "Feed the Future" program, which we mentioned above. The latter has had measurable impact on reducing poverty and problems resulting from chronic malnutrition and hunger. In Bangladesh, where malnutrition rates are among the highest in the world, very satisfactory results have been

\footnotetext{
5 Feed the Future is a US initiative for international development, which began in 2010 by investing food security and agricultural development activities in a select group of developing countries, always in an effort to reduce hunger, malnutrition, poverty and food insecurity. Much of the funding supports 19 "focus" countries selected on the basis of need and ability to succeed. This program supports other countries through the assistance of three "strategic partners" such as Brazil, India and South Africa, to enhance sustainable development on a regional basis.
} 
achieved as a result of its implementation. In Uganda and Honduras poverty has also been able to shrink in rural areas and the average income of those who benefit from the aforementioned program has risen above 50 percent (Alfonso Lenhardt: 2015). However, should be said that in order to achieve this success, the relevant US structures have intensively cooperated with the best US universities and research institutions.

\subsection{Action to Combat Climate Change and Its Impacts}

Climate change is rightly a top priority issue in international discussions because it presents existential threats, especially for people who live in extreme poverty. For the latter, the effects of climate change have become a matter of survival as they risk their food security and living stability. Most of those who are categorized as extremely poor, live in countries with high climate risk. We can mention South Asia and Sub-Saharan Africa, such as Bangladesh, Pakistan, the Democratic Republic of Congo, Madagascar, Nigeria and Uganda.

The United States is committed to reduce climate problems globally, recognizing that climate change really poses a systemic risk. In this regard, President Obama himself signed an executive order that required the Federal Agencies to focus on US international development programs on climate issues. The aim is to provide assistance for reducing carbon levels and promoting sustainable societies in the future.

In cooperation with other international partners, the US has created the Global Alliance for Climate - Smart Agriculture (GACSA), a multilateral coalition to address the challenges of food security and agricultural growth in the context of climate change. Also, the United States plays a leading role in protecting the global environment through the United States Environmental Protection Agency (EPA), which, on the other hand, through USAID, is working with international partners to help the poor to face the climate risks.

Concretely:

- In Ethiopia, they have harmonized scientific and local knowledge to produce appropriate forecasts for the specific needs of this country, so that farmers can make the right decisions for planting, thereby improving their nutritional safety;

- In Indonesia, they have encouraged the construction of infiltrators ponds to ensure stable supply of running water;

- In Nepal, USAID in partnership with NASA has used satellite imagery to help the government of this country, partners and interested parties to manage the landslides, floods and biodiversity degradation (Naom Unger: 2015).

\subsection{Qualitative and Inclusive Education}

Education is another mechanism through which the 2030 Agenda aims to transform the world. Nowadays, 1 in 8 children does not go to school, while 2 in 8 young people cannot read (Global Partnership for Education). As part of the Global Partnership for Education (GPE) initiative, which aims to provide global support for education in developing countries, the United States has contributed \$ 127 million. Through this contribution, it has been possible to create the opportunities to attend school 22.5 million children (White House, Fact Sheet).

The US focus has been mainly in developing countries for which they have designed, funded and monitored concrete plans with standards accepted by all parties. The focus in these countries is due to the high number of children who do not attend school and the poor quality of their education systems. The aim is that through the abovementioned plans to strengthen the technical capacities of these countries and to address the common challenges of education; to improve equality by making inclusive education; as well as fulfilling the quality condition.

Also, First Lady Michelle Obama has offered her contribution to the implementation of the inclusive education for the coming years. She has introduced a new initiative, "Let Girls Learn", which has been very successful in primary education at the global level, and in the growing number of teenage girls who have completed education and today are pursuing their aspirations. 
As part of fulfilling this objective, member countries of the European Union and North American, organized a consultative meeting on 24 and October 25 2016, to ascertain what they have achieved, as well as to determine the further regional and national steps that will have to follow until 2030 (UNESCO, Europe and North America SDG4).

\subsection{Reaction to Humanitarian Crises and Promoting Open Government}

While the number of humanitarian crises in the world has reached alarming levels, the United States continues to be the largest humanitarian donor, offering substantial amounts of food, health and housing in 2016. In co-operation with partners, the United States has continued to encourage the international community to contribute more to humanitarian campaigns. This community has collective responsibility not only to help people in need, but to work together to address the root causes of poverty and to ensure that all people can meet their vital needs. The US has invested in troubled areas such as Sahel, Horn of Africa, South and Southeast Asia in order to help these countries to react better to humanitarian crises, thus reducing the need for emergency and costly interventions in the future.

Also, aiming to promote the economic development and institutional integrity of many countries around the world, the United States together with seven other states initiated the Open Government Partnership (U.S. Department of State: The Open Government Partnership). The latter represents a global initiative to increase transparency, combat crime and corruption, strengthen citizen engagement and utilize new technologies to improve governance. Today, this partnership has expanded from 8 to 70 countries by undertaking a number of international commitments (ibid). Through this initiative, the United States intends to consolidate transparent governance around the world as a necessary condition for sustainable development.

\section{Conclusions}

In order to achieve sustainable development, thus meeting the objectives of the 2030 Agenda, it is necessary to revitalize the global partnership that coincides with another target of the aforementioned agenda. This objective emphasizes the necessity of intensive cooperation between governments, international organizations such as the United Nations and the European Union, civil society, the private sector etc.

To accomplish this goal, the United States promotes the overcoming of traditional models of global cooperation focused on governments. The power of new communication networks needs to replace the barriers of traditional institutions by helping to meet sustainable development goals at lower cost. The goal is to enable more inclusive stakeholder participation, starting from women, young people and civil society groups, small businesses, large industries and private sector financial institutions.

In the American perspective, to make the UN system more cohesive in terms of political guidelines for sustainable development, it's necessary to reform and modernize institutions such as, the United Nations Commission on Sustainable Development (CSD) and United Nations Economic and Social Council (ECOSOC). In this way, the UN will be a more efficient coordination mechanism regarding the overall progress of the sustainable development agenda.

Regarding the EU, US point out that it should take more responsibility, to move from inherited culture of addiction and to be more efficient in terms of sustainable development. But these cannot be achieved if they do not pay attention to the global partnership. Essentially, the United States believes that the implementation of the 2030 Agenda, by the European Union and others, depends on their focused and functional collaboration with partners. The growing challenges of this century, are forcing the US to pay more attention to the issue of partnership and cooperation, making clear once again their tendency to share power with others. As a matter of fact, the 2030 Agenda goals require inten sive global cooperation to be achieved.

\section{References}

Global Partnership for Education, “Transforming the World through Education”. URL (last checked February 2018): http://www.globalpartnership.org/about-us. 
Global Partnership for Education, "Fact Sheet: U.S. Global Development Policy and Agenda 2030". URL (last checked March 2018): http://www.globalpartnership.org/news/fact-sheet-us-global-development-policy-and-agenda-2030.

Inter Action a United Voice for Global Change, "HIV/AIDS, PEPFAR and The Global Fund", URL (last checked February 2018): https://www.interaction.org/choose-to-invest-2017/hivaids-pepfar-global-fund.

Kates, R. W., Parris, Thomas M. \& Leiserowitz, A. A. (2005). "What Is Sustainable Development? Goals, Indicators, Values, and Practice", Environment: Science and Policy for Sustainable Development, 47(3). URL (last checked February 2018): https://www.hks.harvard.edu/sustsci/ists/docs/whatisSD_env_kates_0504.pdf.

Lawson, M. L. Schnepf, R., \& Cook, N. (2016). “The Obama Administration's Feed the Future Initiative” Congressional Research Service, January 29. URL (last checked March 2018): https://www.fas.org/sgp/crs/row/R44216.pdf.

Lenhardt, A. (2015). "How to End Extreme Poverty" Foreign Policy, September 25. URL (last checked March 2018): http://foreignpolicy.com/2015/09/25/how-to-end-extreme-poverty-sustainable-development-goals/.

US Congress. (2004). "Millennium Challenge Corporation”, URL (last checked February 2018): https://www.mcc.gov/about.

UN General Assembly Report. (1987). "Report of the World Commission on Environment and Development: Our Common Future", URL (last checked February 2018): http://www.un-documents.net/our-common-future.pdf

Sessions, M. (2018). “Overview of the President's Emergency Plan for AIDS Relief (PEPFAR)”, Center for Global Development. URL (last checked February 2018): http://www.cgdev.org/page/overview-president\%E2\%80\%99s-emergency-plan-aids-relief-pepfar.

The White House, Office of the Press Secretary For Immediate Release, "Fact Sheet: U.S. Global Development Policy and Agenda 2030: President Obama's Commitment to Global Development" September 27, 2015. URL (last checked April 2018): https://www.whitehouse.gov/the-press-office/2015/09/27/fact-sheet-us-global-development-policy-and-agenda-2030.

The Henry J. Kaiser Family Foundation, Global Health Policy, "The U.S. \& the Global Fund to Fight AIDS, Tuberculosis and Malaria" September 14, 2016. URL 2018 ): http://kff.org/global-health-policy/fact-sheet/the-u-s-the-global-fund-to-fight-aids-tuberculosis-and-malaria/.

The White House, Office of the Press Secretary for Immediate Release, "Fact Sheet: The Global Health Security Agenda", July $28,2015$. URL (last checked April 2018): https://www.whitehouse.gov/the-press-office/2015/07/28/fact-sheet-global-health-security-agenda.

United Nations Development Programme, "Millennium Development Goals", URL (last checked March 2018): http://www.undp.org/content/undp/en/home/sdgoverview/mdg_goals.html.

United Nations, "Transforming our World: The 2030 Agenda for Sustainable Development"

https://sustainabledevelopment.un.org/content/documents/21252030\%20Agenda\%20for\%20Sustainable\%20Development\%20web.pdf.

United Nations, "Paris Climate Change Conference-November 2015", URL (last checked February 2018): http://unfccc.int/meetings/paris_nov_2015/meeting/8926.php

United Nations, "Sustainable Development Knowledge Platform”, (last checked February 2018): https://sustainabledevelopment.un.org/sdgs.

United "The Mations Development Goals Report 2015", http://www.un.org/millenniumgoals/2015_MDG_Report/pdf/MDG\%202015\%20rev\%20(July\%201).pdf.

UNESCO, "Europe and North America SDG4-Education 2030 Regional Consultation". URL (last checked April 2018): http://en.unesco.org/node/265549.

USAID, Gender Equality and Women's Empowerment, “Closing Gaps”, August 24, 2015. URL (last checked April 2018):https://www.usaid.gov/what-we-do/gender-equality-and-womens empowerment/closing-gaps.

U.S. Department of State “The Open Government Partnership”. URL (last checked April 2018): http://www.state.gov/j/ogp/.

US Environmental Protection Agency, URL (last checked April 2018): https://www.epa.gov/aboutepa.

Unger, N. (2015). "Living on the Edge in a World of Changing Climate", USAID, December 16. URL (last checked April 2018): https://blog.usaid.gov/2015/12/living-on-the-edge-in-a-world-of-changing-climate/. 